\title{
ПОНЯТИЙНЫЕ АСПЕКТЫ И ОСНОВНЫЕ ТЕНДЕНЦИИ МИРОВОГО РЫНКА ИНТЕЛЛЕКТУАЛЬНОЙ СОБСТВЕННОСТИ
}

\section{CONCEPTUAL ASPECTS AND MAIN TRENDS OF THE WORLD INTELLECTUAL PROPERTY MARKET}

\section{R. Gurkov}

Summary. In the article discussed one of the commercial forms of international technological exchange - trade in intellectual property (IP). The author concretizes the conceptual apparatus of IP. At the same time, the author analyzes the world intellectual property market, identifies its main trends, in particular, and defines its sectoral structure and the main technology developers - patent applicants. At the same time, studied the dynamics of royalties and license payments in the intellectual property market, determined its geographical structure the main leaders of the recipient (exporters) and payers (importers) of IP.

Keywords: international technological exchange, technology transfer, intellectual property, patents, trademarks, industrial designs, royalties, royalties, high-tech industry, technologies, developing countries, South-East Asia. $\ll \mathbf{B}$ 1967 г. после принятия Конвенции об учреждении Всемирной организацию интеллектуальной собственности (ВОИС)» [1], предшественником которой начиная с 1892 года оставалась организация «Объединенные международные бюро по охране интеллектуальной собственности» [2], больше известно как «BIRPI» (орган, ответственный за осуществление «Парижской конвенции об охране промышленной собственности» [3] и «Бернской конвенции об охране литературных и художественных произведений» [4]), научным сообществом был признан и вошел в широкое использование термин «интеллектуальная собственность».

В тоже время усилилась необходимость формирования нормативной правовой базы, регламентирующей обмен ИС. В частности, например, членами Всемирной торговой организации (ВТО) было заключено Соглашение по торговым аспектам прав интеллектуальной собственности (ТРИПС), а также создан Комитет по передаче технологий в рамках Конференции ООН по торговле и развитию (ЮНКТАД).
Гурков Родион Александрович

Аспирант, Всероссийская академия внешней торговли Министерства экономического развития

Российской Федерации; Ведущий советник отдела стран Юго-Восточной Азии и Океании Департамента стран Азии, Африки, Латинской Америки Минпромторга России gurkov_rodion@mail.ru

Аннотация. В статье рассматривается одна из коммерческих форм осуществления международного технологического обмена — торговля объектами интеллектуальной собственности (ИС). Автором конкретизируется понятийный аппарат ИС. Одновременно автором проводится анализ мирового рынка интеллектуальной собственности, выявлены его основные тенденции, в частности, определена его отраслевую структуру и основные разработчики технологий — патенто-заявители. Вместе с тем изучена динамика роялти и лицензионных платежей на рынке интеллектуальной собственности, определена его географическая структура - основные лидеры страны-получатели (экспортеры) и плательщики (импортеры) ИС.

Ключевые слова: международный технологический обмен, интеллектуальная собственность, патенты, торговые знаки, промышленные образцы, роялти, лицензионные платежи, технологии, технологические отрасли промышленности, развивающиеся страны, Юго-Восточная Азия.

Определение представленное в документах Всемирной организации интеллектуальной собственности, гласит, что «интеллектуальная собственность представляет собой права, относящиеся к литературным, художественным и научным произведениям, исполнительской деятельности артистов, звукозаписи, радиои телевизионным передачам, изобретениям во всех областях человеческой деятельности, научным открытиям, промышленным образцам, товарным знакам, знакам обслуживания, фирменным наименованиям и коммерческим обозначениям, защите против недобросовестной конкуренции, а также все другие права, относящиеся к интеллектуальной деятельности в производственной, научной, литературной и художественной областях» [5].

В Соглашении ТРИПС понятие «интеллектуальной собственности раскрывается через все категории интеллектуальной собственности, которые являются предметом разделов 1-7 части II Соглашения. К этим категориям относятся: авторское право и смежные права; патенты; товарные знаки; промышленные образцы; ге- 


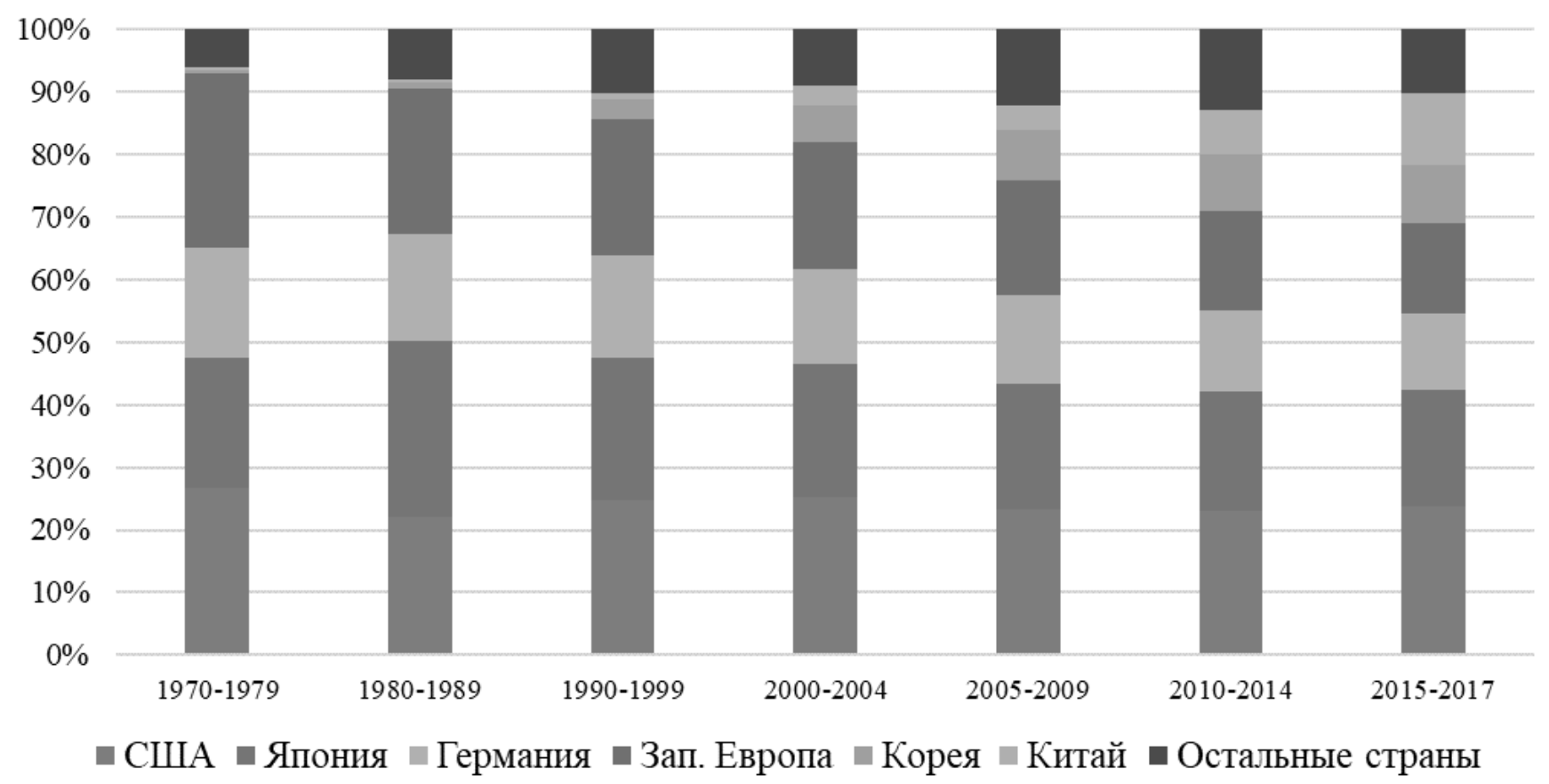

Рис. 1. Изменение доли ведущих экономик в патентовании Источник: [9]

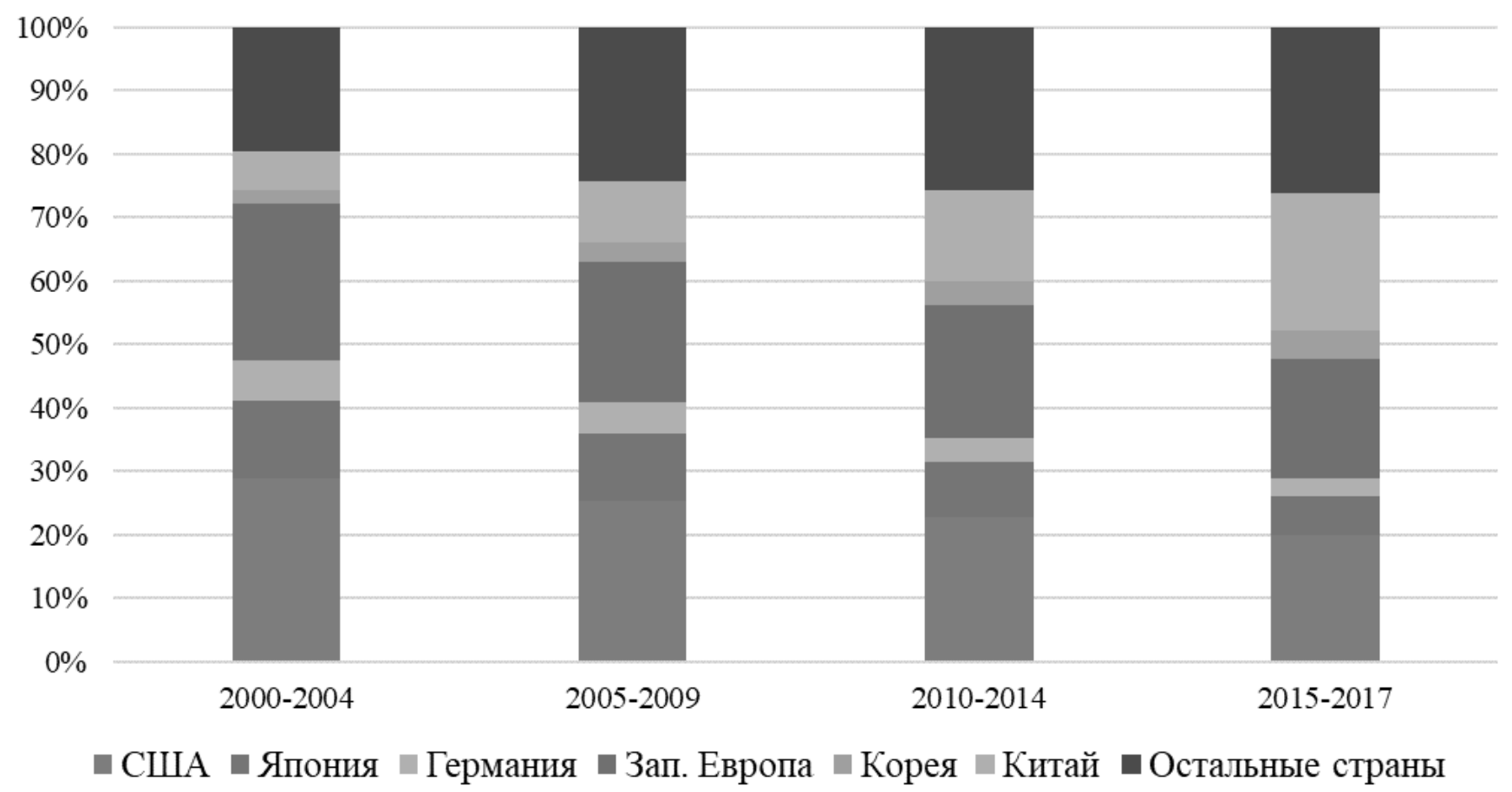

Рис. 2. Изменение доли ведущих экономик в публикации научных работ Источник: [9] 
ографические указания; топологии интегральных схем; охрана закрытой информации» [6].

«Лицензиар (владелец технологии) позволяет, а также способствует лицензиату (покупателю технологии) в использовании изобретения или технологии в виде ноу-хау. Лицензиар получает вознаграждение за использование лицензиатом технологий. Оплата может иметь вид: роялти (периодические процентные отчисления от себестоимости лицензированной продукции) и паушальных платежей (выплата лицензиару твердо зафиксированной суммы за 2-4 раза). Продажа лицензий выгодна в том случае, когда доход от продажи лицензии превосходит расходы по контролю использования лицензии и упущенную выгоду от монополии на эту технологию» [7].

В настоящее время патенты, авторские права и товарные знаки являются ключевыми инструментами правовой защиты объектов ИС.

В соответствии с определением (ВОИС) «патент это исключительное право, предоставленное на изобретение, которое представляет собой продукт или процесс, обеспечивающий новый способ выполнения чего-либо или предлагающий новое техническое решение. Для получения патента техническая информация об изобретении должна быть раскрыта общественности в патентной заявке. Авторские права - это юридический термин, используемый для описания прав, которыми обладают создатели на свои литературные и художественные произведения. Произведения, на которые распространяется авторское право, варьируются от книг, музыки, картин, скульптур и фильмов до компьютерных программ, баз данных, рекламных объявлений, карт и технических чертежей. Под товарными знаками понимаются обозначения компаний, служащее для индивидуализации и отличия товары или услуги одного предприятия от товаров или услуг других предприятий. Товарные знаки защищены правами интеллектуальной собственности» [8].

Одновременно стоит отметить, что торговля объектами интеллектуальной собственности является одной из коммерческих форм международного технологического обмена $[15,16]$.

В течение большей части периода 1970-2000 годов две трети всего патентования в мире приходилось на три страны - США, Японию и Германию (Рисунок 1, Рисунок 2). При этом с учетом остальных западноевропейских экономик, в частности Великобритании, Франции, Швейцарии и Италии, этот показатель составлял примерно $90 \%$.
Тем не менее в течение последних трех десятилетий доля остальных стран в производстве новых технологий медленно росла, в основном за счет нескольких западноевропейских стран, увеличившись с 6\% в начале $1970-x$ годов до более чем 13\% в начале $2000-x$ годов. Причем лишь небольшая часть этого роста была связана с Республикой Корея и Китаем.

За последние два десятилетия эта тенденция значительно усилилась в контексте как технологических (патенты), так и научных результатов. С 2010 года доля Китая, Кореи и остальных страны мира составила треть всей патентной деятельности.

Расширение географии научных публикаций происходит еще более активно - примерно за тот же период доля Китая, Кореи и остальных стран мира в этой области увеличилась с $27 \%$ до $58 \%$.

Если включить две азиатские экономики Китая и Кореи в группу Западной Европы, США и Японии, то можно увидеть, что доля остальных стран мира все равно увеличивается по обоим показателям производства знаний.

Основным фактором увеличения доли остальных стран мира в системе патентования является усиление роли развивающихся азиатских стран, как субъектов глобальной инновационно-технологической сферы деятельности.

Рассмотрим основные тенденции мирового рынка интеллектуальной собственности.

В соответствии с данными публикации, выпущенной Всемирной организации интеллектуальной собственности «Мировые показатели интеллектуальной собственности» [10], в 2019 году число поданных разработчиками инновационных продуктов заявок на патенты сократилось на 3,0\% и составило 3,224 млн. заявок в сравнении с показателем 2018 г. (Рисунок 3), что преломило тенденцию роста патентных заявок, длившуюся последнее десятилетие с начала финансового кризиса 2009 г. (Рисунок 4).

Одновременно число заявок на регистрацию товарных знаков и промышленных образцов выросло до 15,1 млн. на 5,9\% и до 1,36 млн. на 1,3\% соответственно (Рисунок 3).

Фактором снижения патентной активности стало сокращение числа заявок из Китая, однако страна и по сей день продолжает занимать лидирующие позиции по числу поданных заявок на патенты начиная с 2011 года - 1,4 млн. 


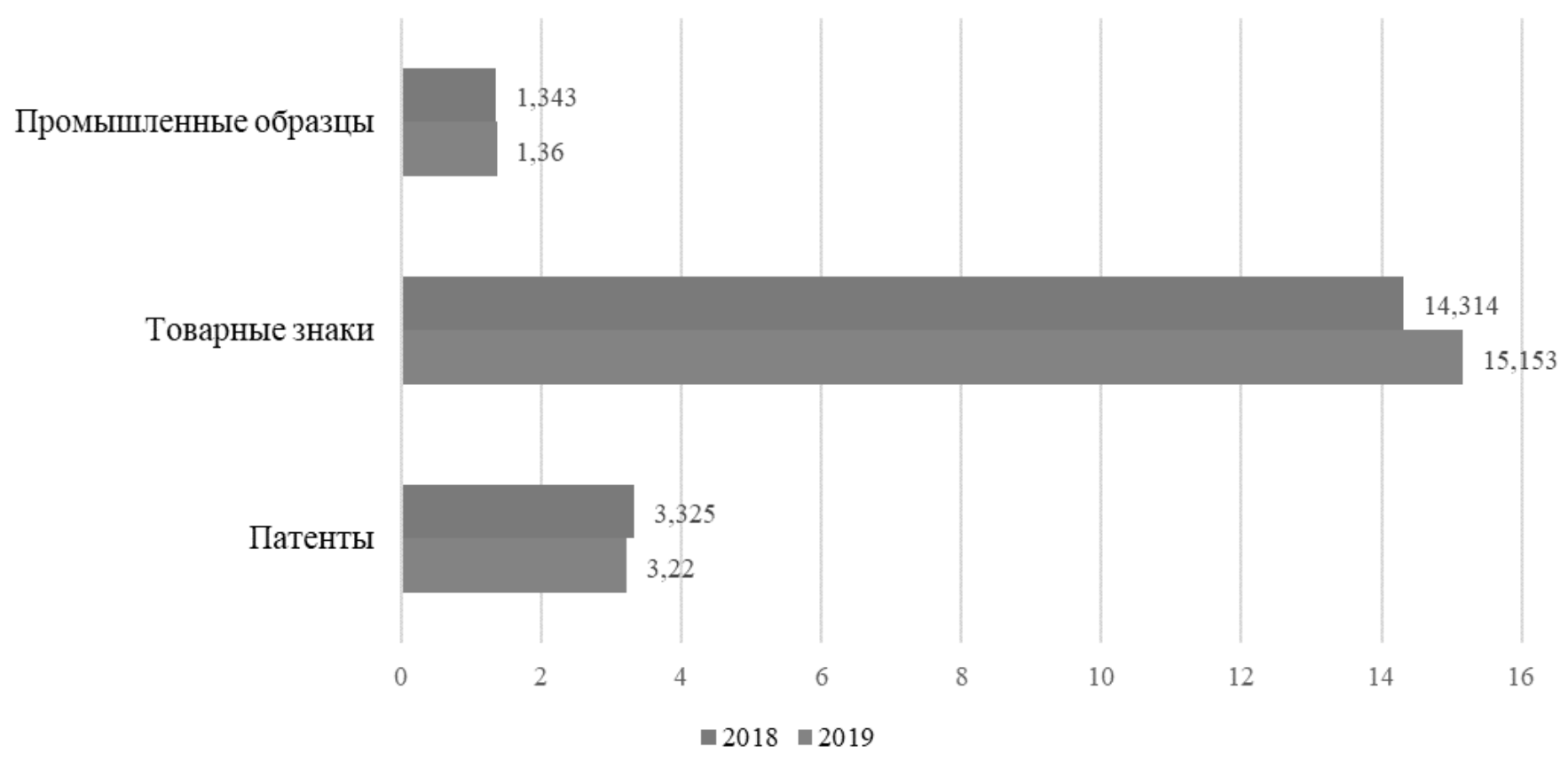

Рис. 3. Общемировое количество заявок по созданию интеллектуальной собственности млн. шт., 2018-2019 гг.

Источник: Составлено автором на основе данных [11].

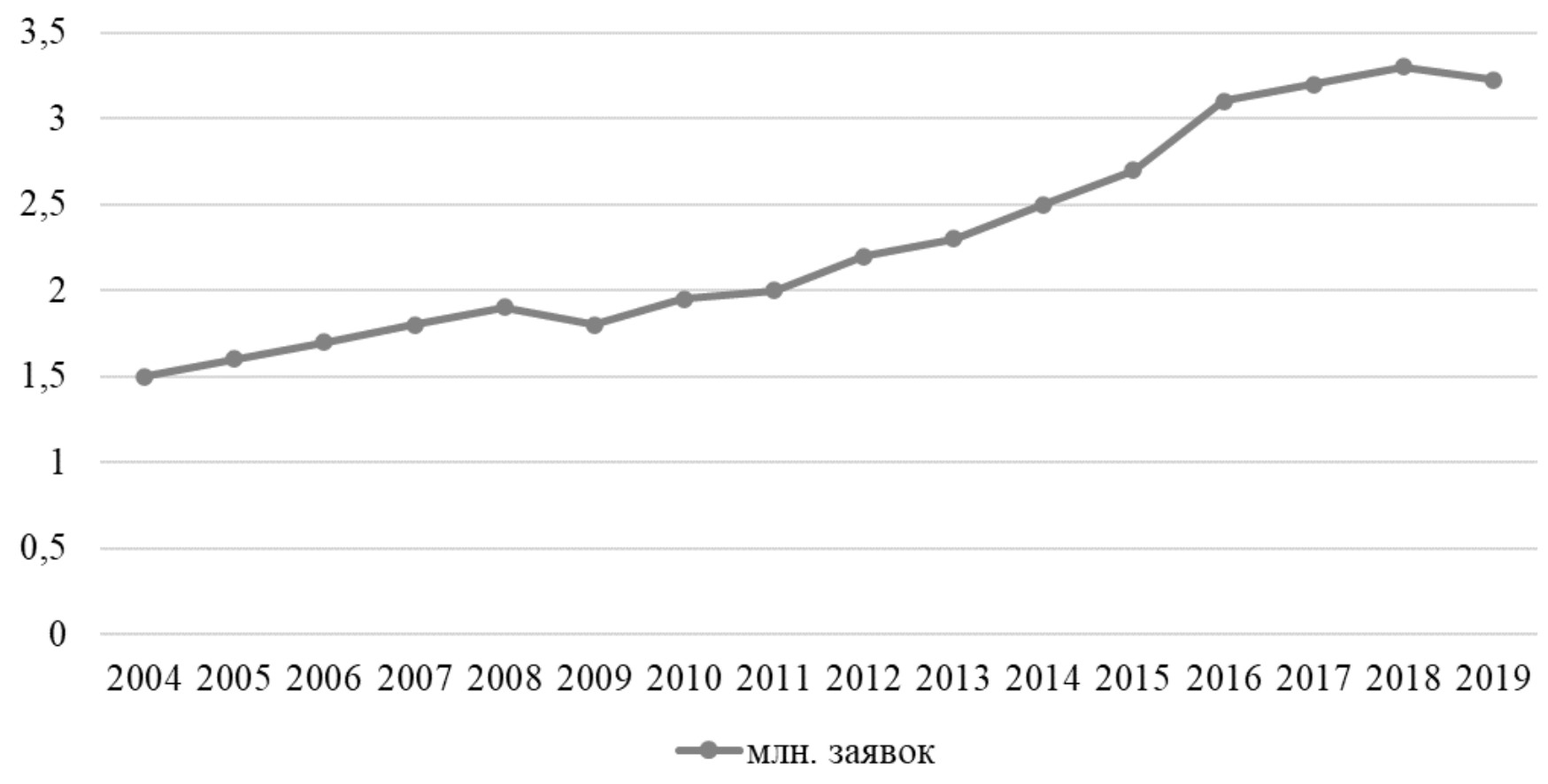

Рис. 4. Общемировое количество патентных заявок млн. шт., 2004-2019 гг. Источник: Составлено автором на основе данных [11]. 


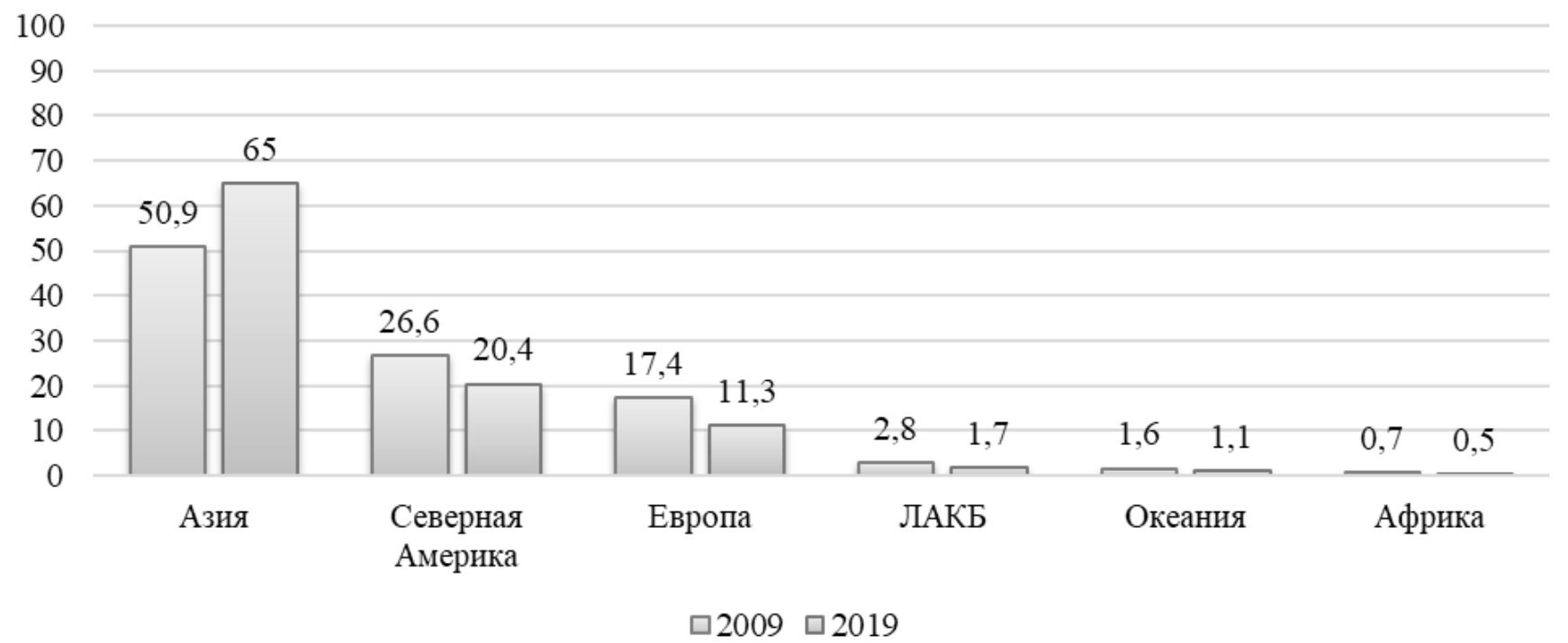

Рис. 5. Доля числа заявок на патенты по регионам, 2009 и 2019 гг. Источник: Составлено автором на основе данных [11].

Патентное ведомство США занимает второе место по количеству полученных заявок в 2019 г. занимает (621453 заявок), после которого следуют Япония 307969, Республика Корея - 218975 и Европейское патентное ведомство (ЕПВ) - 181479. В совокупности в 2019 г. пятерка этих патентных ведомств занимает долю 85\% всех заявок.

В число лидеров по объему поданных заявок также вошли ведомства Германии, Индии, Канады, Россия, Австралии, Бразилии, Великобритании, Сингапура, Индонезии и Таиланда.

Азиатский регион продолжает укреплять свои позиции и в 2019 году на долю патентных ведомств стран Азии приходилось 65\% мирового объема всех поданных заявок. Прирост в сравнении с показателем 2009 года составил 14,1\%, в основном за счет показателей патенто-заявителей из Китая (Рисунок 5).

На ведомства стран североамериканского континента в 2019 году пришлось примерно 20\% от всех поданных в мире заявок, стран Европы - около 11\%, а совокупная доля стран Африки, Латинской Америки и Карибского бассейна и Океании - 3,3\%.

Подача заявок в иностранные патентные ведомства служит показателем освоения новых рынков, в данной области лидерами остаются резиденты США, Япония, Германия, Китай и Республика Корея.

В 2019 году количество действующих в мире патентов в сравнении с аналогичным показателем 2018 года достигло 15 млн. (+ 7\%) из них 3,1 млн. патентов США, 2,7 млн. патентов Китая, 2,1 млн. патентов Японии, 1 млн. патентов Республики Корея.

По данным патентной статистики в 2018 году (последний год, за который имеются полные данные в связи с задержкой между подачей заявки и публикацией) компьютерные технологии чаще всего фигурировали в патентных заявках - 234667 всех поданных заявок. За ним следовали электротехника - 215828 заявок, измерительная техника - 164255 заявок, медицинская техника - 147542 заявок и технологии цифровой связи - 146416 заявок (Таблица 1).

В совокупности на эти пять областей приходилось $28,4 \%$ всех опубликованных заявок на патентование по всему миру. Эта доля сохраняется на протяжении последних семи лет. Среди 20 ведущих технологических позиций наибольший среднегодовой рост числа патентных заявок в период с 2008 по 2018 года наблюдался в станкостроении $(+13,4 \%)$, прочей спецтехники $(+11,4 \%)$, химическом машиностроении $(+11,4 \%)$ и продовольственной химии $(+11,4 \%)$, технологии окружающей среды $(+11,4 \%)$, цифровые методы управления (+10,9\%). За ними следовали такие технологические позиции, как компьютерные технологии $(+5,8 \%)$ и медицинские технологии $(+6,5)$.

Среди десяти ключевых стран патенто-заявителей в период с 2016 по 2018 года Китай и США чаще подавали заявки на компьютерные технологии; Япония и Республика Корея - в области электротехники; Франция и Германия - в области транспорта; Швейцария и Ве- 
Таблица 1. Мировые показатели поданных заявок на патенты по технологическим отраслям, 2008-2018 года.

\begin{tabular}{|c|c|c|c|c|c|c|}
\hline $\begin{array}{l}\text { Отраслевая } \\
\text { группа }\end{array}$ & Технология & 2008 г. & 2013 г. & 2018 г. & $\begin{array}{l}\text { \% от } \\
\text { общего } \\
\text { числа } \\
\text { заявок }\end{array}$ & $\begin{array}{l}\text { Средний } \\
\text { прирост } \\
2008- \\
2018 \text { гг. (\%) }\end{array}$ \\
\hline \multirow{8}{*}{ Электро-техника } & Электрические машины, аппараты & 105240 & 161425 & 215828 & 6,7 & 7,4 \\
\hline & Аудио-визуальные технологии & 89036 & 77060 & 84910 & 2,7 & $-0,5$ \\
\hline & Телекоммуникационное оборудование & 67118 & 51822 & 58569 & 1,8 & $-1,4$ \\
\hline & Цифровая связь & 69759 & 101123 & 146416 & 4,6 & 7,7 \\
\hline & Основные коммуникационные процессы & 17750 & 16496 & 16290 & 0,5 & $-0,9$ \\
\hline & Компьютерные технологии & 133095 & 167186 & 234667 & 7,3 & 5,8 \\
\hline & Цифровые методы управления & 22108 & 33994 & 61970 & 1,9 & 10,9 \\
\hline & Полупроводники & 79893 & 86936 & 85523 & 2,7 & 0,7 \\
\hline \multirow{5}{*}{ Инструменты } & Оптические & 74090 & 65941 & 73276 & 2,3 & $-0,1$ \\
\hline & Измерительные & 72287 & 103998 & 164255 & 5,1 & 8,6 \\
\hline & Анализа биологических материалов & 11558 & 13102 & 19347 & 0,6 & 5,3 \\
\hline & Контроля & 28745 & 37290 & 76597 & 2,4 & 10,3 \\
\hline & Медицинские технологии & 78317 & 94881 & 147542 & 4,6 & 6,5 \\
\hline \multirow{11}{*}{ Химия } & Органическая химия & 56034 & 55818 & 67202 & 2,1 & 1,8 \\
\hline & Биотехнологии & 36600 & 45798 & 65562 & 2,0 & 6,0 \\
\hline & Фармацевтика & 76203 & 80128 & 102853 & 3,2 & 3,0 \\
\hline & Молекулярная химия, полимеры & 28409 & 37179 & 53900 & 1,7 & 6,6 \\
\hline & Пищевая химия & 23683 & 42146 & 69971 & 2,2 & 11,4 \\
\hline & Основные химические элементы & 41663 & 60805 & 92275 & 2,9 & 8,3 \\
\hline & Металлургия & 34557 & 52827 & 79735 & 2,5 & 8,7 \\
\hline & Лакокрасочные материалы & 30711 & 39155 & 49910 & 1,6 & 5,0 \\
\hline & Нано-технологии & 2756 & 4547 & 5600 & 0,2 & 7,3 \\
\hline & Химическое машиностроение & 35609 & 48966 & 104736 & 3,3 & 11,4 \\
\hline & Технологии окружающей среды & 22751 & 33976 & 66826 & 2,1 & 11,4 \\
\hline \multirow{8}{*}{$\begin{array}{l}\text { Машино- } \\
\text { строение }\end{array}$} & Обработка & 43224 & 55795 & 103680 & 3,2 & 9,1 \\
\hline & Станкостроение & 38423 & 61237 & 116133 & 3,6 & 11,7 \\
\hline & Двигатели, турбины, насосы & 43825 & 62418 & 65807 & 2,1 & 4,1 \\
\hline & Печатные и текстильные станки & 33982 & 36005 & 49470 & 1,5 & 3,8 \\
\hline & Спецтехника & 46881 & 66635 & 138379 & 4,3 & 11,4 \\
\hline & Аппараты термообработки & 25968 & 36430 & 55016 & 1,7 & 7,8 \\
\hline & Механические элементы & 47837 & 59104 & 84275 & 2,6 & 5,8 \\
\hline & Транспортные средства & 67992 & 89618 & 141048 & 4,4 & 7,6 \\
\hline \multirow{4}{*}{ Другое } & Мебель, игры & 45338 & 52462 & 89011 & 2,8 & 7,0 \\
\hline & Другие потребительские товары & 32193 & 41198 & 64110 & 2,0 & 7,1 \\
\hline & Строительная техника & 53330 & 73968 & 122747 & 3,8 & 8,7 \\
\hline & Неизвестные позиции & 37201 & 31591 & 25863 & 0,8 & $-3,6$ \\
\hline \multicolumn{2}{|l|}{ Общее значения: } & 1754166 & 2179060 & 3199299 & 100,0 & 6,2 \\
\hline
\end{tabular}

Примечание: Минимальный срок между датой подачи патентной заявки и датой ее публикации составляет 18 месяцев. Источник: Составлено автором на основе данных [11], [12]. 


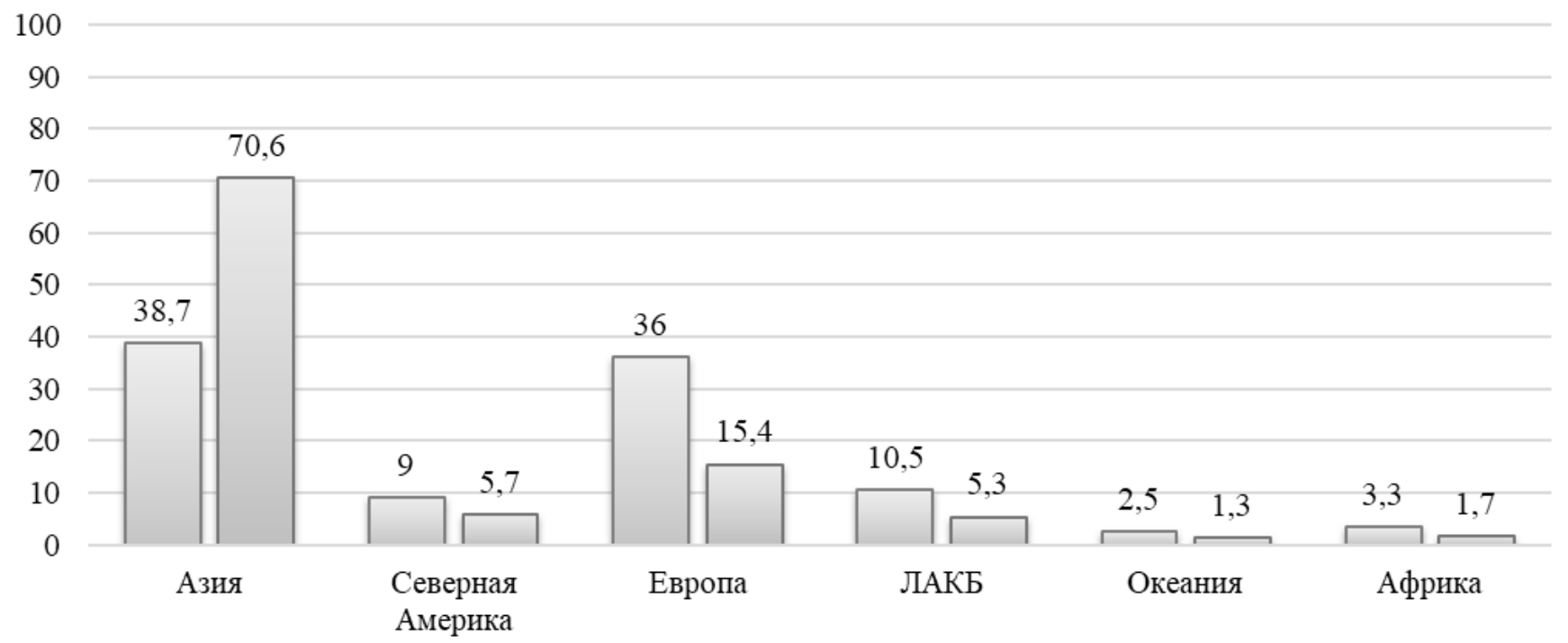

$\square 2009 \square 2019$

Рис. 6. Доля числа регистраций товарных знаков по регионам, 2009 и 2019 гг. Источник: Составлено автором на основе данных [11]

ликобритания - в области фармацевтики; Нидерланды - в области медицинских технологий; Российская Федерация - в области пищевой химии.

Среди крупных развивающихся стран в период с 2015-2017 годов разработчики технологий из Индии (18,1\% от общего числа опубликованных заявок) и Мексики (9,9\%), подали значительное число заявок в фармацевтике, из Бразилии (7,2\%) в других специальных машинах, из Малайзии $(7,4 \%)$ в компьютерных технологиях, из Таиланда $(15,9 \%)$ в оптике; из Турции $(8,4 \%)$ в транспорте.

Статистика показателей количества заявок на новые товарные знаки свидетельствует, что в 2019 г. во всем мире было подано 11,5 млн. заявок, что на 630 тыс. заявок больше показателя 2018 года $(+5,8 \%)$, а число классов товарных знаков составило 15,2 млн. (+5,9\%), продолжая рост десятый год подряд.

Лидером по количеству заявок на товарные знаки в 2019 году остается Китай - 7,8 млн. заявок (+6,4\%), за которым следуют ведомства США - 672681 (+5,1\%), Японии - 546244 (+6,7\%), Ирана - 454925 (+18,4\%) и ЕПВ - 407712 (+3,8\%). В число ведущих стран по количеству заявок на товарные знаки также вошли Индия, Франция, Россия, Корея, Турция, Бразилия и Вьетнам.

Ведомства азиатского региона в 2019 году приняли около 2/3 всех поданных заявок на товарные знаки, а рост относительно показателя 2009 года со- ставил 32\%. В свою очередь Европейские ведомства в 2019 году приняли лишь 15,4\% общемирового числа заявок, доля заявок стран североамериканского континента составила лишь 5,7\%, а на долю стран Африки, Латинской Америки и Карибского бассейна, и Океании пришлось 8,3\%, что на 8\% меньше, чем в 2009 году (Рисунок 6).

В 2019 г. на долю заявок на товарные знаки по товарным позициям пришлось 69,6\%, на услуги - 30,4\%. Основными классами с наибольшим числом заявок стали: научные, фотографические, измерительные приборы, записывающее оборудование, компьютеры и программное обеспечение (11\%), реклама и бизнес-управление $(7,6 \%)$, научные и технологические услуги, компьютерные комплектующие и ПО (5,5\%), фармацевтические препараты (5,5\%), косметические препараты $(5,2 \%)$, швейная промышленность $(4,7 \%)$, образование и культурно-развлекательные мероприятия (4,7\%).

Китай остается лидером по числу действующих регистраций товарных знаков с показателем 25,2 млн. (43\% общего объема). Также в число лидеров вошли США 2,8 млн. регистраций, Индия и Япония - по 2 млн. регистраций соответственно. В 2019 году общее число регистраций товарных знаков составило 58,2 млн. (+15,2\% от показателя 2018 года).

Число заявок, содержащих описание 1,36 млн. промышленных образцов в 2019 году составило 1,04 млн. увеличившись на 1,7\% в сравнении с показателем пре- 


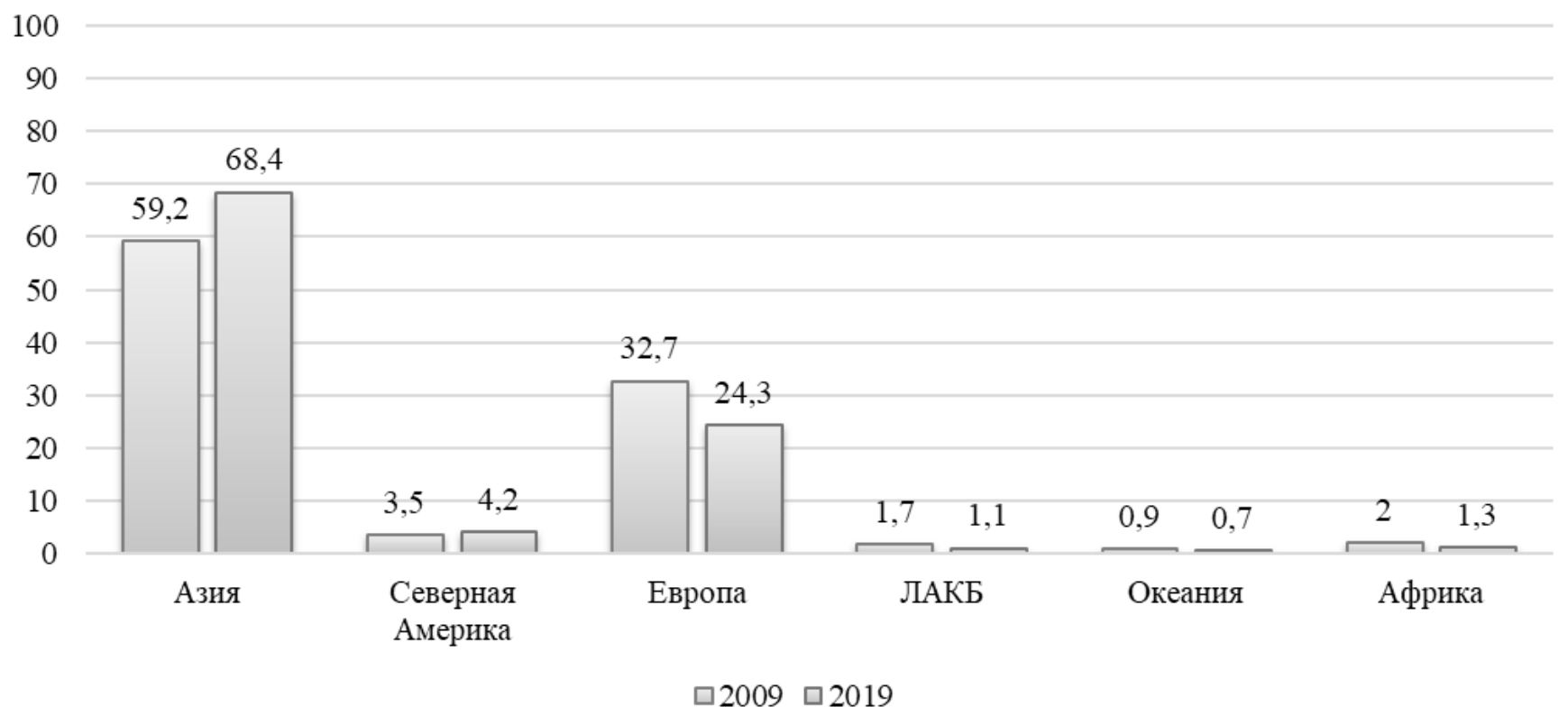

Рис. 7. Доля числа регистраций промышленных образцов по регионам, 2009 и 2019 гг. Источник: Составлено автором на основе данных [11]

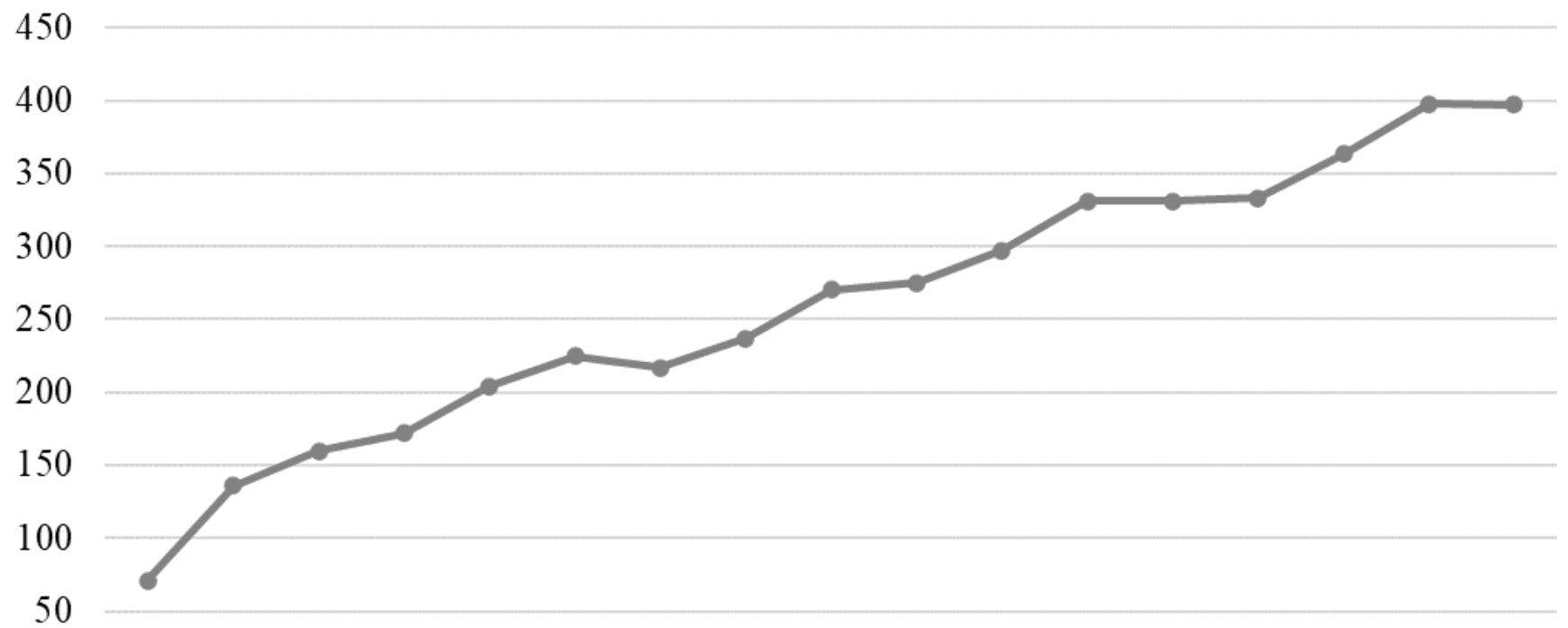

0

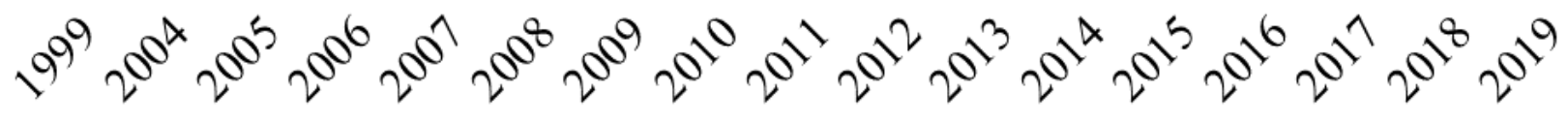

млрд. долл. США

Рис. 8. Динамика мирового объем поступлений в виде роялти и лицензионных платежей (млрд. долл. США)

Источник: составлено автором на основе [13]. 
Таблица 2. Основные страны-получатели роялти и других лицензионных платежей - продавцы ИС (млрд. долл. США)

\begin{tabular}{|l|l|l|l|l|l|l|}
\hline Страна & $\mathbf{2 0 0 4}$ & $\mathbf{2 0 0 9}$ & $\mathbf{2 0 1 5}$ & $\mathbf{2 0 1 8}$ & $\mathbf{2 0 1 9}$ & $\begin{array}{l}\text { Доля от общего } \\
\text { объема (2019 г.) }\end{array}$ \\
\hline США & 56,9 & 85,7 & 111,1 & 118,8 & 117,4 & $30,0 \%$ \\
\hline Япония & 15,7 & 21,6 & 36,5 & 45,5 & 46,8 & $12,0 \%$ \\
\hline Нидерланды & 18,3 & 26,7 & 37,5 & 38,4 & 41,8 & $10,7 \%$ \\
\hline Германия & 4,4 & 7,2 & 24,1 & 36,3 & 36,2 & $9,3 \%$ \\
\hline Швейцария & 5,2 & 12 & 17,4 & 25,8 & 29,8 & $7,6 \%$ \\
\hline Великобритания & 9,7 & 13,8 & 20,7 & 26,2 & 24,4 & $6,2 \%$ \\
\hline Франция & 7,2 & 12,6 & 15,2 & 17,7 & 15,9 & $4,0 \%$ \\
\hline Ирландия & 0,7 & 1,7 & 8,1 & 14,4 & 11,9 & $3,0 \%$ \\
\hline Сингапур & 0,4 & 1,4 & 8,6 & 8,3 & 8,5 & $2,2 \%$ \\
\hline Швеция & 3,4 & 4,6 & 8,6 & 7,7 & 8,2 & $2,1 \%$ \\
\hline Республика Корея & 1,9 & 3,2 & 6,5 & 7,7 & 7,7 & $1,9 \%$ \\
\hline Китай & 0,2 & 0,4 & 1,1 & 5,5 & 6,6 & $1,7 \%$ \\
\hline Канада & 3,2 & 3,6 & 4 & 5,5 & 5,7 & $1,4 \%$ \\
\hline Италия & 2,9 & 3,2 & 3 & 4,9 & 4,5 & $1,1 \%$ \\
\hline Дания & 1,2 & 2,6 & 2,1 & 3,3 & 3,8 & $1,0 \%$ \\
\hline ЕС-27 & 39,1 & 68 & 112,7 & 141 & 141,1 & $36,1 \%$ \\
\hline Развивающиеся страны Азии & 0,34 & 0,5 & 0,7 & 1,3 & 1,5 & $0,4 \%$ \\
\hline Всего: & 135,5 & 214,5 & 325,5 & 393,5 & 390,5 & $100 \%$ \\
\hline
\end{tabular}

Источник: составлено автором на основе [13].

дыдущего года, из них китайскими разработчиками было подано 711 тыс. заявок, европейскими - 113 тыс., корейскими - 69 тыс., американскими - 50 тыс., турецкими - 46 тыс.

На долю заявок патентных ведомств стран азиатского региона пришлось более $2 / 3$ (68,4\%) мирового числа заявок на промышленные образцы, стран Европы 24,3\%, Северной Америки - 4,2\%, Африки - 1,3\%, Латинской Америки и Карибского бассейна - 1,1\%, Океании $-0,7 \%$ (Рисунок 7).

Наибольшую долю от общего числа заявок на создание новых промышленных образцов содержалось в описании предметов мебели $(9,5 \%)$, одежды $(8,1 \%)$ и упаковку (7,3\%). Большая часть действующих промышленных образцов (4,07 млн.) приходится на Китай (1,79 млн. регистраций, 44\% общемирового числа промышленных образцов), Корею - 358 тыс., США 360 тыс., Японию - 261 тыс., и ЕПВ - 236 тыс.

Подсчет стоимостных объемов международных операций в сфере объектов интеллектуальной собственности осложнен конфиденциальным характером большого количества таких сделок. В этой связи, при оценке интенсивности международного технологического обмена следует использовать имеющуюся информацию об объемах роялти и других лицензионных отчислений.
По итогам 2019 г. стоимостной показатель мирового объема роялти и лицензионных платежей составил 397 млрд. долл. США. что в 5,6 раз больше аналогичного показателя 1999 года (Рисунок 8).

Динамику оборота роялти и лицензионных платежей на рынке интеллектуальной собственности, а также его географическую структуру - основных лидеров, стран-получателей (экспортеров ИС) и плательщиков (импортеров ИС), можно представить следующим образом (Таблица 2, Таблица 3).

По итогам 2019 года совокупная доля стран Северной Америки и EC-27 в общем объеме поступлений за использование интеллектуальной собственности составила 67,5\%, в стоимостном объеме - 264,2 млрд. долл. США. Данный факт свидетельствует о том, что именно США, ЕС и Канада являются ключевыми экспортными центрами интеллектуальной собственности. Одной из причин лидерства этих стран является высокоинтенсивный внутрифирменный технологический обмен. Так, например, более 65\% экспорта интеллектуальной собственности США формируется из отчислений дочерних зарубежных структур крупных высокотехнологических компаний [14]. В число лидеров также вошла Республика Корея, которая занимает 12\% совокупных поступлений от продажи ИС или 46,8 млрд. долл. США. 
Таблица 3. Основные страны-плательщики роялти и других лицензионных платежей покупатели ИС (млрд. долл. США)

\begin{tabular}{|l|l|l|l|l|l|l|}
\hline Страна & $\mathbf{2 0 0 4}$ & $\mathbf{2 0 0 9}$ & $\mathbf{2 0 1 5}$ & $\mathbf{2 0 1 8}$ & $\mathbf{2 0 1 9}$ & $\begin{array}{l}\text { Доля от общего } \\
\text { объема (2019 г.) }\end{array}$ \\
\hline Ирландия & $\mathbf{1 9}, 2$ & 35 & 70,7 & 85,4 & 94,2 & $21,4 \%$ \\
\hline Нидерланды & 24,2 & 34,4 & 72,1 & 45,1 & 43,2 & $9,8 \%$ \\
\hline США & 22,8 & 29,4 & 35,2 & 43,9 & 42,7 & $9,7 \%$ \\
\hline Китай & 4,5 & 11 & 22 & 35,7 & 34,4 & $7,8 \%$ \\
\hline Япония & 13,6 & 16,8 & 17 & 22 & 26,3 & $6 \%$ \\
\hline Великобритания & 9 & 9,8 & 12,9 & 14,4 & 17,5 & $4 \%$ \\
\hline Швейцария & 2,6 & 7 & 13 & 13,6 & 17,2 & $3,9 \%$ \\
\hline Сингапур & 8 & 13,4 & 19,4 & 16,8 & 16,2 & $3,7 \%$ \\
\hline Германия & 4,5 & 7 & 10,1 & 16 & 16,1 & $3,6 \%$ \\
\hline Франция & 5,8 & 8,3 & 15,6 & 14,3 & 13 & $3 \%$ \\
\hline Канада & 6,5 & 8,9 & 10,7 & 11,8 & 11,4 & $2,6 \%$ \\
\hline Республика Корея & 4,6 & 7,3 & 10 & 9,8 & 9,9 & $2,3 \%$ \\
\hline Индия & 0,6 & 1,9 & 5 & 7,9 & 7,9 & $1,8 \%$ \\
\hline Российская Федерация & 1,05 & 4 & 5,6 & 6,3 & 6,8 & $1,5 \%$ \\
\hline Швеция & 1,4 & 1,8 & 4,2 & 4,9 & 6,8 & $1,5 \%$ \\
\hline ЕС-27 & 46,3 & 108,1 & 202,1 & 202,5 & 211,4 & $48,1 \%$ \\
\hline Развивающиеся страны Азии & 4,3 & 7,2 & 12,7 & 17,6 & 18 & $4,1 \%$ \\
\hline Всего: & 135,6 & 243,5 & 391,5 & 429,7 & 439,2 & $100 \%$ \\
\hline
\end{tabular}

Источник: составлено автором на основе [13].

Удельный вес развивающихся стран Азии, а именно: Индии, Индонезии, Малайзии, Таиланда, Филиппин, Вьетнама в 2019 году составил лишь 0,4\% - 1,5 млрд. долл. США, что свидетельствует о крайне низкой коммерческой привлекательности их разработок и заинтересованности зарубежных стран в покупке. Однако в случае рассмотрения данного показателя в совокупности с показателями Китая значения претерпевают пятикратное увеличение - 2,1\% или 8,1 млрд. долл. США, что в целом сопоставимо с показателями некоторых развитых стран, например, Швеции, Сингапура, Республики Кореи или даже Ирландии.

Рассматривая ситуацию со стороны основных импортеров интеллектуальной собственности, на долю стран Северной Америки и ЕС-27 приходится порядка $60,4 \%-265,5$ млрд. долл. США. Лидером в данном списке является Ирландия занимаю пятую часть мирового импорта интеллектуальной собственности - 94,2 млрд. долл. США. Стоит отметить значительную роль Китая, увеличивший за последние 15 лет свою долю в 2 раза с 3,3\% в 2004 г. (4,5 млрд. долл. США) до 7,8\% в 2019 г. (34,4 млрд. долл. США).

Показатель импорта интеллектуальной собственности развивающихся стран Азии в 3 раза превосходит соответствующий показатель по экспорту. В 2019 г. на долю этих стран приходилось чуть более 4\% миро- вого импорта - 18 млрд. долл. США. В совокупности с показателем Китая импорт интеллектуальность собственности составляет порядка 1/10 или $12 \%$ мирового потребления (52,5 млрд. долл. США).

В целом имеющаяся статистика свидетельствует о том, что география распределения международного технологического обмена объектами интеллектуальной собственности обусловлена различными факторами, в числе которых находятся геополитические, торгово-экономические, финансовые и другие. Основным вектором направленности потоков интеллектуальной собственности является Запад - Запад и Запад - Юг.

Таким образом, количество новых разработок продолжает неизменно расти из года в год. Ключевым центром создания новых технологий являются страны Азии: Япония, Корея, Китай, Индия, Индонезия, Малайзия, Таиланд, Филиппины, Вьетнам. На долю этих стран в 2019 г. приходилось более 65\% мирового числа поданных заявок на патенты, более 70\% общемирового количества заявок на новые товарные знаки, а также почти 70\% заявок на разработку промышленных образцов.

Наибольшее число разработок создается в таких областях, как компьютерные технологии, электротехника, 
измерительная техника, медицинская техника, а также технологии цифровой связи. В совокупности на эти пять областей приходится 28,4\% всех опубликованных заявок на патентование по всему миру, и эта доля сохраняется на протяжении последних семи лет.

Страны Северной Америки (США, Канада) и Европейского Союза являются ключевыми продавцами и потребителями объектов интеллектуальной собственности с долей участия 67,5\% и 60,4\% в мировом экспорте и импорте технологий соответственно.
Одновременно отмечается крайне низкий уровень коммерциализации собственных разработок развивающихся стран Азии, а также высокая степень зависимости в технологиях, разрабатываемых в европейских и североамериканской странах.

На географию потоков международного технологического обмена объектами интеллектуальной собственности влияет ряд факторов, в число которых входят геополитические, торгово-экономические, финансовые и другие аспекты сотрудничества.

\section{ЛИТЕРАТУРА}

1. Конвенция, учреждающая Всемирную организацию интеллектуальной собственности, от 14 июля 1967 г. [Электронный ресурс]. — URL: https:// wipolex.wipo.int/ru/treaties/textdetails/12830

2. Hughes J. A Short History of Intellectual Property' in Relation to Copyright (July 11, 2009). Cardozo Law Review. 2012. Vol. 33. Issue 4. Pр. 1293-1340. [Электронный ресурc].—URL: https://papers.ssrn.com/sol3/papers.cfm?abstract_id=1432860

3. Парижская конвенция по охране промышленной собственности от 20 марта 1883 г. [Электронный ресурc]. — URL: https://www.wipo.int/publications/ ru/details.jsp?id=311

4. Бернская конвенция по охране литературных и художественных произведений от 9 сент. 1886 г. [Электронный ресурc]. — URL: https://www.wipo.int/ treaties/ru/text.jsp?file_id $=283698$

5. Официальный сайт Всемирной организации интеллектуальной собственностью. Что такое интеллектуальная собственность? [Электронный ресурc].— URL: https://www.wipo.int/publications/ru/details.jsp?id=4528

6. Соглашение по торговым аспектам прав интеллектуальной собственности от 15 апр. 1994 г. [Электронный pecypc].— URL: https://www.wipo.int/ publications/ru/details.jsp?id=311

7. Международные экономические отношения: учеб. пособие / Дралин А.И., Михнева С.Г. Изд. 2-е перераб. и доп. — Пенза: Информационно-издательский центр ПГУ, 2006

8. Официальный сайт Всемирной организации интеллектуальной собственности (ВОИС) [Электронный ресурс]. — URL: https://www.wipo.int/

9. WIPO based on PATSTAT, PCT and Web of Science data (European Patent Office's (EP0) Worldwide Patent Statistical Database (PATSTAT, April 2019) and WIPO's Patent Cooperation Treaty (PCT) collections.

10. World Intellectual Property Organization. World Intellectual Property Indicators 2020 [Электронный ресурc].— URL: https://www.wipo.int/publications/en/ details.jsp?id=4526

11. WIPO Statistics Database, September 2020.

12. EPO PATSTAT database, September 2020.

13. Статистические показатели электронной базы данных World Bank. [Электронный ресурс].— URL: https://data.worldbank.org/indicator/

14. Шакиров А. Противодействие США нарушениям прав интеллектуальной собственности на международных рынках. Вестник Института экономики Российской академии наук, № 4/2012. С. 115

15. Основы международной торговли: Учеб. пособие / Под ред. Козака Ю.Г., Логвиновой Н.С. — ЦУЛ, 2005. С. 113

16. Международный менеджмент: Учебник для вузов / Пол ред. С.Э. Приноварова. — СПб.: Питер, 2000. С. 506

(с) Гурков Родион Александрович (gurkov_rodion@mail.ru ). Журнал «Современная наука: актуальные проблемы теории и практики» 